\title{
Strategic Human Resource Practice: A Functional Framework and Causal Model of Leadership Behavior, Job Satisfaction, Organizational Commitment, and Job Performance
}

\author{
Kijpokin Kasemsap \\ Suan Sunandha Rajabhat University, Bangkok, Thailand \\ kijpokinkasemsap@yahoo.com
}

\begin{abstract}
Research objectives were to determine a functional framework and to synthesize a causal model of leadership behavior, job satisfaction, organizational commitment, and job performance of sugar company employees in Thailand. The study reported the responses of 591 operational employees from 24 sugar companies operating in different parts of Thailand. Data were analyzed with descriptive statistics using SPSS (version 11.5) and path analysis using LISREL (version 8). Research findings indicated that dimensions of leadership behavior, job satisfaction, and organizational commitment have mediated positive effect on job performance. Organizational commitment positively mediates the relationships between leadership behavior and job performance and between job satisfaction and job performance. Furthermore, leadership behavior is positively correlated with job satisfaction.
\end{abstract}

Keywords: Causal Model, Job Performance, Job Satisfaction, Leadership Behavior, Organizational Commitment

\section{Introduction}

Leadership behavior has direct and matchless impact on the work environment, work outcomes, and the success of organizations (Kritsonis, 2004). To have high level of organizational performance and effectiveness, it is vital that both employee and employer should have high level of satisfaction (Lok \& Crawford, 2003); therefore, their level of satisfaction has positive relationship to the success of the company. The dissatisfaction of employee will lead them to less work commitment and high turnover intention from the organization, as well as physical withdrawal or they may retreat from the organization emotionally or mentally. On the other hand, job dissatisfaction not only increases intention to quit but also reduces the contribution of the employee to the organization (Lok \& Crawford, 2003). Research objectives were to determine a functional framework and to synthesize a causal model of leadership behavior, job satisfaction, organizational commitment, and job performance of sugar company employees in Thailand.

\section{Review of Literature}

Daft (2005) defined leadership behavior as an influence relationship among leaders and followers who intend real changes and outcomes that reflect their shared purposes. The most influential contingency approach to leadership is the Path-Goal theory, developed by Robert House (Robbins, 2005). This theory states the main goal of the leader is to help subordinates attain the subordinates' goals effectively, and to provide them with the necessary direction and support to achieve their own goals as well as those of the organization (Silverthorne, 2001). The behavior of effective leadership can assist in the improvement of organizational performance (Fenwick \& Gayle, 2008). Leadership style is the way that leaders behave toward or treat the individuals they are leading (Ehrhart, 2004). Drucker (1993) indicated that the quality and performance of managers are the key criteria in deciding organizational success. The $45 \%$ to $65 \%$ of the total factors causing success or failure of organization are decided by leaders (Bass, 1990). Leadership style has influence on employees' behavior, including their adoption of the firm's strategy and organizational value and has been linked to both organizational outcomes and employees' work performance (Ehrhart, 2004). Supportive leadership includes leadership behavior such as talking to people, supporting their efforts, giving them hope, and solving their problems of decision-making process (Rollinson \& Broadfield, 2002). Supportive leaders are the ones who show concern for their followers and establish an open, friendly, and approachable group climate, along with the ability to equally treat their co-workers (Hanson, 2003; Lunenburg \& Ornstein, 2000).

Emotions and personal expectations are taken into consideration in supportive leadership. Leaders tend to stray from the path they follow for the sake of happiness and satisfaction of their followers (House, 
1971). Supportive leadership is the most effective leadership behavior on subordinates (House \& Terence, 1991). Directive leadership is described as the situation where leader gives complete and essential directives on a particular subject (House, 1971; House \& Terence, 1991). Telling the expectations to those under the command (followers), planning, programming, controlling goal performance, and bringing out standards in behavior are the behavior of directive leadership (Hanson, 2003; Lunenburg \& Ornstein, 2000). Directive leaders in organizations could be described as having characteristics such as dominating over the employees, observing whatever teachers do, controlling activities, performing autocratic characteristics, and talking more than listening (Hoy \& Miskel, 2001). Participative leadership is associated with consensus, consultation, delegation, and involvement (Bass, 1981). Results revealed that employees who perceive their managers as adopting consultative or participative leadership behavior are more committed to their organizations, more satisfied with their jobs and higher in their performance (Yousef, 2000). Because of the consultative nature of participative leadership, it has the potential to enhance the dissemination of organizational and managerial values to employees. Employees who work for a participative leader tend to exhibit greater involvement, commitment, and loyalty more than employees who work under a directive leader (Bass, 1981). Concerning Valez (1972), job satisfaction has two components of intrinsic job satisfaction (level of satisfaction with features associated with the job itself) and extrinsic job satisfaction (level of satisfaction with various features associated with the environment).

Williams and Hazer (1986) stated that job satisfaction is associated with aspects of work environment and would develop more quickly than organizational commitment, which would require a worker to make a more global assessment of his relationship or her relationship to the organization. Job satisfaction is an immediate antecedent of intention to leave the workplace and turnover. Unsatisfied workers will leave their jobs more than their satisfied colleagues (Martin, 1990). According to Fogarty (1994), job satisfaction refers to the extent to which employees gain enjoyment from their efforts in the workplace. Satisfaction can be considered as either positive or negative evaluative judgments made by people about their job or work situation (Weiss, 2002). Job satisfaction is defined as a person's evaluation of his or her job and work context (McShane, 2004) and as a global feeling about the job or as a related constellation of attitudes about various aspects or facets of the job (Spector, 1997). Job satisfaction is a pleasurable or positive emotional state resulting from the appraisal of one's job or job experiences (Locke, 1976). Job satisfaction has been identified as a major requirement for organizations which aim to achieve excellence in their organizations (Chiboiwa et al., 2011). Job satisfaction has been associated with organizational commitment (Boles et al., 2007; Cohen, 2006; Cooper-Hakim \& Viswesvaran, 2005; Pool \& Pool, 2007). Mosadeghrad (2003) defined job satisfaction as an attitude that people have about their jobs and the organizations in which they perform these jobs. Furthermore, Robbins and Judge (2009) defined job satisfaction as a positive feeling about one's job resulting from an evaluation of its characteristics.

Job satisfaction is generally recognized as a multifaceted construct that includes employee feelings about a variety of both intrinsic and extrinsic job factors. Furthermore, job satisfaction is an emotional reaction and behavioral expression to a job that results from individual assessment of his or her work achievement, office environment, and work life (Golbasi et al., 2008). Job satisfaction includes several related attitudes. For example, people can experience emotional responses to remuneration, promotion opportunities, relations with superiors and colleagues, and the work itself (McKenna, 2006). According to Randeree and Chaudhry (2007), job satisfaction affects productivity of employees in a culturally diversified environment. When employees are satisfied with their jobs, they effectively perform in their jobs (Golparvar \& Javadian, in press). Furthermore, Dormann and Zapf (2001) concluded that job satisfaction is one of the most researched concepts. It serves as central to work and organizational psychology. It serves as mediator for creating relationship between work conditions, on the one hand, and individual/organizational outcome on the other hand (Dormann \& Zapf, 2001). According to Allen and Meyer (1990), organizational commitment has three components of affective commitment, continuance commitment, and normative commitment. Affective commitment refers to the employee's emotional attachment to, identification with, and involvement in, the organization (Allen \& Meyer, 1990). Continuance commitment refers to commitment based on the costs that employee associates with leaving the organization (Allen \& Meyer, 1990). Normative commitment refers to employee's feeling of obligation to remain with organization (Allen \& Meyer, 1990).

Organizational commitment refers to an employee's belief and loyalty to the organization (Hackett et al., 2001). Organizational commitment is a subjective measure that captures employees' perceptions of their identification with their organizational core values, their intent to stay with their organization, and their 
willingness to exert more effort than expected by their organization (Mowday et al., 1979). Organizational commitment is essential for reaching such challenging goals (Klein et al., 1999) as these goals require more effort and typically have lower chances of success than are easy goals (Latham, 2007). Organizational commitment has been conceptualized as a psychological state or mindset that binds individuals to a course of action relevant to one or more targets, and a willingness to persist in a course of action (Cooper-Hakim \& Viswesvaran, 2005). Organizational commitment is a strong belief in and acceptance of the organizational goals, willingness to exert considerable effort on behalf of the organization and a desire to maintain organizational membership (Porter et al., 1974). As such, commitment is different from motivation that commitment independently influences behavior of other motives and attitudes, and may lead to persistence to a course of action even if this conflicts with motives (Meyer \& Herscovitch, 2001). Interest in organizational commitment has been largely stimulated by its demonstrated positive relationship to work behaviors such as job satisfaction, high productivity, and low turnover (Cohen, 2003). Herscovitch and Meyer (2002) defined organizational commitment as the degree to which an employee identifies with the goals and values of the organization and is willing to exert effort to help it succeed.

Organizational commitment is of considerable interest to psychologists because there is strong evidence of links between high levels of commitment and favorable organizational outcomes (Angle \& Perry, 1983). Organizational commitment is a form of psychological contract, which employees make in response to the benefits provided by the organization (Angle \& Perry, 1983). With the increasing speed and scale of change in organizations, managers are constantly seeking ways to generate employees' commitment, which translates to the competitive advantage and the improved work attitudes such as job satisfaction, performance, absenteeism, and turnover intentions (Lok \& Crawford, 2001). Research studies indicated that leadership behavior is positively related to job satisfaction (Appelbaum et al., 2004; Yousef, 2000). Furthermore, Kim (2002) stated that there are positive relationships among participative management style, job satisfaction, and organizational commitment. Furthermore, leadership behavior is positively linked to job performance (Dawson et al., 1972; Euske \& Jackson, 1980; Swanson \& Johnson, 1975). Organizational commitment is positively correlated with job performance (Baugh \& Roberts, 1994; Brett et al., 1995; Ward \& Davis, 1995). Employees, who have an affective commitment toward organization (Allen et al., 2003) have high loyalty and job performance (Eisenberger et al., 1990). Job satisfaction can motivate employees to work hard and to promote organizational performance (Huang \& Chi, 2004; Lam et al., 2002). In addition, Ribelin (2003) concluded that leadership can improve job satisfaction and organizational performance. Previous studies demonstrated that job satisfaction is a predictor of organizational commitment (Caykoylu et al., 2007; Chen, 2007; Yang, 2010).

\section{Methodology}

Data for this study were collected from 591 operational employees out of 10,743 operational employees working in the 24 sugar companies in Thailand by using Yamane's formula (Yamane, 1970) for a 96\% confidence level with a $4 \%$ margin of error by the proportional random sampling method. All the constructs were operationalized based on a seven - point Likert scale ranging from 1 (strongly disagree) to 7 (strongly agree). Data were analyzed with descriptive statistics using SPSS (version 11.5) and assessed with confirmatory factor analysis (CFA) to confirm the heterogeneity of all constructs and path analysis (Joreskog \& Sorborn, 1993) to detect the cause-effect relationships among various dimensions of main constructs of the study using LISREL (version 8) on a structured questionnaire containing standard scales of leadership behavior, job satisfaction, organizational commitment, and job performance, besides some demographic details like age, education, and tenure with the organization. The 13 -item measure of leadership behavior as participative ( 5 items), supportive ( 4 items), and directive ( 4 items) developed by Harris and Ogbonna (2001), based on previous research of House (1971). Organizational commitment was measured using Organizational Commitment Questionnaire (OCQ) developed by Allen and Meyer (1990) comprising 18 items measuring affective commitment, continuance commitment, and normative commitment. Job performance was measured using questionnaire developed by Stevens et al. (1978) comprising two dimensions of job performance, namely quality of performance and productivity. Job satisfaction was measured using the Minnesota Satisfaction Questionnaire (MSQ) developed by Weiss et al. (1967) comprising 20 items measuring intrinsic job satisfaction and extrinsic job satisfaction.

\section{Results and Discussion}

A functional framework and a causal model were synthesized. Research findings indicated that 
dimensions of leadership behavior, job satisfaction, and organizational commitment have mediated positive effect on job performance. Organizational commitment positively mediates the relationships between leadership behavior and job performance and between job satisfaction and job performance. Furthermore, leadership behavior is positively correlated with job satisfaction.

\section{Figure 1: Functional Framework and Causal Model}

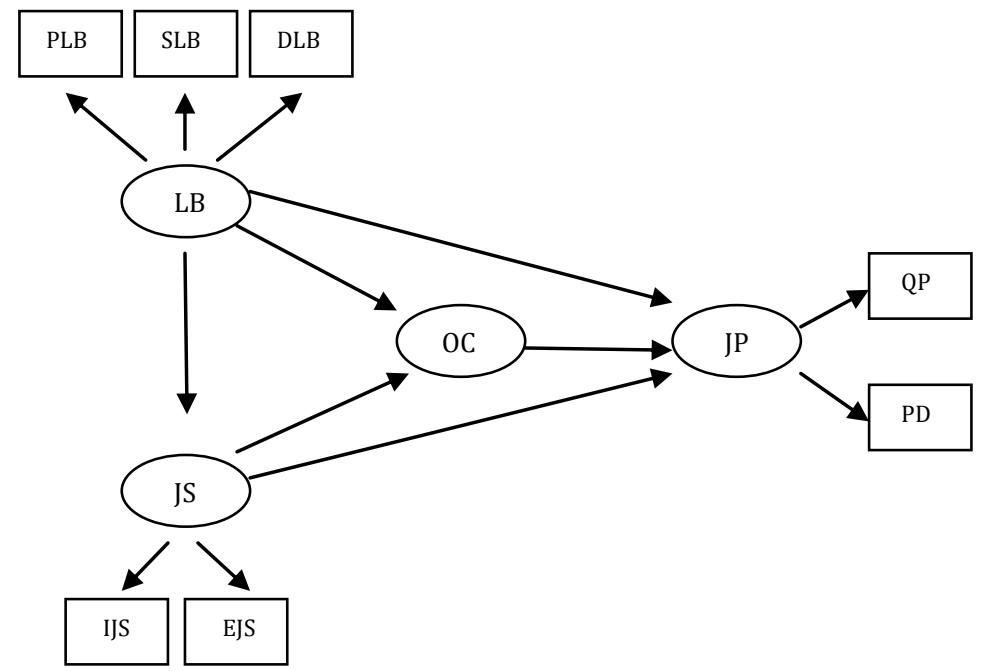

Key: LB = Leadership Behavior, PLB = Participative Leadership Behavior, SLB = Supportive Leadership Behavior, DLB $=$ Directive Leadership Behavior, JS = Job Satisfaction, IJS = Intrinsic Job Satisfaction, EJS = Extrinsic Job Satisfaction, $\mathrm{OC}=$ Organizational Commitment, JP = Job Performance, $\mathrm{QP}=$ Quality of Performance, $\mathrm{PD}=$ Productivity

Regarding the functional framework and causal model, there are lots of researchers studying the relationships of leadership behavior, job satisfaction, organizational commitment, and job performance in a wide variety of fields. The functional framework was positively compatible with the following research findings. Leadership behavior, job satisfaction, and organizational commitment are positively linked to job performance. Several methodological studies demonstrated that employees who are supported from their organization are satisfied with their job (Riggle, et al., 2009; Tansky \& Cohen, 2001). Employees who are satisfied with their jobs give a better performance (Robbins \& Judge, 2009) and contribute to organizational effectiveness (i.e., commitment and turnover intentions). The result that job satisfaction influences various facets of organizational commitment would be of benefit for managers in the sense that they should make every effort to improve job satisfaction for their employees to enhance commitment to their organizations. Employees who attach to their organization show better performance and more meaningful contributions (Meyer \& Allen, 1997). Organizations or supervisors should spend reasonable and intensive time with their employees through supportive activities like socialization and training (Karatepe \& Uludag, 2007). Employers or managers would like their employees to be willing to work on behalf of the organization, to accept the goals and values of the organization, and to have a strong sense of motivation to remain in their organization. Leaders need to realize the impact of their personal leadership styles upon their employees' commitment to the workplace, and that the success of their endeavors is dependent on the shared values and norms within the organization.

\section{Conclusion}

The purposes of this study were to determine the functional framework and to synthesize the causal model of leadership behavior, job satisfaction, organizational commitment, and job performance for sugar company employees in Thailand. The findings showed that the leadership behavior, job satisfaction, and organizational commitment have the strength to mediate positive effect on job performance. In relation to the functional framework and causal model, this result was the extent to which leadership behavior, job satisfaction, and organizational commitment have mediated positive effect on job performance. Organizational commitment positively mediates the relationships between leadership behavior and job performance and between job satisfaction and job performance. Furthermore, leadership behavior is positively correlated with job satisfaction. Employees who perceive their superiors as adopting consultative or participative leadership behavior are more committed to their organizations, more satisfied with their jobs, and higher in their job performance. Furthermore, the results that the 
relationships between organizational commitment and the work outcomes of job satisfaction and job performance are positive and significant indicate that those who are committed to their organizations are more satisfied with their jobs. According to the results, improving organizational commitment and job performance requires the adoption of the appropriate leadership behavior in order to enhance the level of job satisfaction and in turn the levels of both organizational commitment and job performance.

Recommendations: Leadership behavior and job satisfaction help organizations move toward better job performance through organizational commitment. Organizations aiming to increase job performance and achieve business goals should focus on developing leadership behavior, job satisfaction, and organizational commitment. Future research can benefit from a larger sample to bring more statistical power and a higher degree of representation. This study was done by empirically investigating Thai firms. Cultural limitation should be considered and it is suggested that future research should be done in other variables (i.e., organizational justice, organizational citizenship behavior, organizational learning, leadermember exchange, job involvement, and employee engagement) to develop job performance and achieve business goals.

\section{References}

Allen, N. J. \& Meyer, J. P. (1990). The measurement and antecedents of affective, continuance, and normative commitment to the organization. Journal of Occupational Psychology, 63(1), 1-18.

Allen, D. G., Shore, L. M. \& Griffeth, R. W. (2003). The role of perceived organizational support and supportive human resource practices in the turnover process. Journal of Management, 29(1), 99118.

Angle, H. L. \& Perry, J. L. (1983). Organizational commitment: Individual and organizational influences. Work and Occupation, 10(2), 123-146.

Appelbaum, S., Bartolomucci, N., Beaumier, E., Boulanger, J., Corrigan, R. \& Dore, I. (2004). Organizational citizenship behavior: A case study of culture, leadership and trust. Management Decision, 42(1), 13-40.

Bass, B. M. (1981). Personal selling and transactional/transformational leadership. Journal of Personal Selling and Sales Management, 17(3), 19-28.

Bass, B. M. (1990). Handbook of Leadership: A Survey of Theory and Research. New York: Free Press.

Baugh, S. \& Roberts, R. (1994). Professional and organizational commitment among engineers: Conflicting or complementary. IEEE Transactions on Engineering Management, 41(2), 108-114.

Boles, J. S., Madupalli, R., Rutherford, B. \& Wood, J. A. (2007). The relationship of facet of salesperson job satisfaction with affective organization commitment. Journal of Business \& Industrial Marketing, 22(5), 311-321.

Brett, J., Cron, W. \& Slocum, J. (1995). Economic dependency on work: A moderator of the relationship between organizational commitment and performance. Academy of Management Journal, 38(1), 261-271.

Caykoylu, S., Egri, C. P. \& Havlovic, S. (2007). Organizational commitment across different employee groups. The Business Review, Cambridge, 8(1), 191-197.

Chen, Y. (2007). Relationships among service orientation, job satisfaction, and organizational commitment in the international tourist hotel industry. Journal of American Academy of Business, 11(2), 71-82.

Chiboiwa, M. W., Samuel, M. O. \& Chipunza, C. (2011). Evaluation of job satisfaction and organizational citizenship behavior: Case study of selected organizations in Zimbabwe. African Journal of Business Management, 5(7), 2910-2918.

Cohen, A. (2003). Multiple Commitments in the Workplace: An Integrative Approach. Mahwah: Lawrence Erlbaum Associates.

Cohen, A. (2006). The relationship between multiple commitments and organizational citizenship behavior in Arab and Jewish culture. Journal of Vocational Behavior, 69(1), 105-118.

Cooper-Hakim, A. \& Viswesvaran, C. (2005). The construct of work commitment: Testing an integrative framework. Psychological Bulletin, 131(2), 241-259.

Daft, R. L. (2005). The Leadership Experience. Vancouver: Thomson-Southwestern.

Dawson, J., Meese, L. \& Phillips, J. (1972). Effects of instructor-leader behavior on student performance. Journal of Applied Psychology, 56(5), 369-376. 
Dormann, C. \& Zapf, D. (2001). Job satisfaction: A meta-analysis of stabilities. Journal of Organizational Behavior, 22(5), 483-504.

Drucker, P. F. (1993). The Practice of Management. New York: Harper Business.

Ehrhart, M. G. (2004). Leadership and procedural justice climate as antecedents of unit level organizational citizenship performance. Personnel Psychology, 57(1), 61-94.

Euske, K. J. \& Jackson, D. W. (1980). Performance and satisfaction of bank managers. Journal of Bank Research, 11(1), 36-42.

Fenwick, F. J. \& Gayle, C. A. (2008). Missing links in understanding the relationship between leadership and organizational performance. International Business \& Economic Research Journal, 7(5), 67-78.

Fogarty, T. J. (1994). Public accounting experience: The influence of demographic and organizational attributes. Managerial Auditing Journal, 9(7), 12-20.

Golbasi, Z., Kelleci, M. \& Dogan, S. (2008). Relationships between coping strategies, individual characteristics and job satisfaction in a sample of hospital nurses: Cross-sectional questionnaire survey. International Journal of Nursing Studies, 45(12), 1800-1806.

Golparvar, M. \& Javadian, A. (in press). The model of relation between psychological contracts, commitment and satisfaction with Psychological Models and Approaches.

Hackett, R. D., Hausdorf, P. A. \& Lapierre, L. M. (2001). Understanding the links between work commitments constructs. Journal of Vocational Behavior, 58(3), 392-413.

Hanson, E. M. (2003). Educational Administration and Organizational Behavior. Boston: Pearson Education.

Harris, L. C. \& Ogbonna, E. (2001). Leadership style and market orientation: An empirical study. European Journal of Marketing, 35(5/6), 744-764.

Herscovitch, L. \& Meyer, J. P. (2002). Commitment to organizational change: Extension of a threecomponent model. Journal of Applied Psychology, 87(3), 474-487.

House, R. J. (1971). A path-goal theory of leader effectiveness. Administrative Science Quarterly, 16(9), 321-338.

House, R. J. \& Terence, R. M. (1991). Path-goal theory of leadership. In B. Staw (Ed.). Psychological Dimensions of Organizational Behavior. New York: Macmillan Publishing.

Hoy, W. K. \& Miskel, C. G. (2001). Educational Administration: Theory, Research and Practice. New York: McGraw-Hill.

Joreskog, K. G. \& Sorbom, D. (1983). LISREL 8: User's Reference Guide. Chicago: Scientific Software International.

Karatepe, O. M. \& Uludag, O. (2007). Conflict, exhaustion, and motivation: A study of frontline employees in Northern Cyprus hotels. International Journal of Hospitality Management, 26(3), 645-665.

Kim, S. (2002). Participative management and job satisfaction: Lessons for management leadership. Public Administration Review, 62(2), 231-241.

Klein, H. J., Wesson, M. J., Hollenbeck, J. R. \& Alge, B. J. (1999). Goal commitment and the goal setting process: Conceptual clarification and empirical synthesis. Journal of Applied Psychology, 84(6), 885-896.

Kritsonis, W. A. (2004). Leadership in organizations: National implications. International Journal of Scholarly Academic Intellectual Diversity, 9(1), 1-8.

Latham, G. P. (2007). Work Motivation: History, Theory, Research, and Practice. Thousand Oaks: Sage Publications.

Locke, E. A. (1976). The nature and causes of job satisfaction. In M. Dunnette (Ed.). Handbook of Industrial and Organizational Psychology. Chicago: Rand McNally.

Lok, P. \& Crawford, J. (2001). Antecedents of organizational commitment and the mediating role of job satisfaction. Journal of Managerial Psychology, 16(8), 594-613.

Lok, P. \& Crawford, J. (2003). The effect of organizational culture and leadership style on job satisfaction and organizational commitment: A cross-national comparison. Journal of Management Development, 23(4), 321-338.

Lunenberg, F. C. \& Ornstein, A. C. (2000). Educational Administration: Concepts and Practices. Belmont: Wadsworth/Thomson Learning.

Martin, B. J. (1990). A successful approach to absenteeism. Nursing Management, 21(8), 45-48.

McKenna, E. (2006). Business Psychology and Organizational Behavior. New York: Psychology Press.

McShane, S. L. (2004). Canadian Organizational Behavior. Toronto: McGraw-Hill Ryerson. 
Meyer, J. P. \& Allen, N. J. (1997). Commitment in the Workplace: Theory, Research and Application. London: Sage Publications.

Meyer, J. P. \& Herscovitch, L. (2001). Commitment in the workplace: Toward a general model. Human Resource Management Review, 11(3), 299-326.

Mosadeghrad, A. M. (2003). The role of participative management (suggestion system) in hospital effectiveness and efficiency. Research in Medical Sciences, 8(3), 85-89.

Mowday, R., Steers, R. \& Porter, L. (1979). The measure of organizational commitment. Journal of Vocational Behavior, 14(2), 224-227.

Pool, S. \& Pool, B. (2007). A management development model: Measurement organizational commitment and its impact on job satisfaction among executives in a learning organization. Journal of Management Development, 26(4), 353-369.

Porter, L. W., Steers, R. M., Mowday, R. T. \& Boulian, P. V. (1974). Organizational commitment, job satisfaction, and turnover among psychiatric technicians. Journal of Applied Psychology, 59(5), 603-609.

Randeree, K. \& Chaudhry, A. G. (2007). Leadership in project managed environments: Employee perceptions of leadership styles within infrastructure development in Dubai. International Review of Business Research Papers, 3(4), 220-232.

Ribelin, P. J. (2003). Retention reflects leadership style. Nursing Management, 34(8), 18-19.

Riggle, R. J., Edmondson, D. R. \& Hansen, J. D. (2009). A meta-analysis of the relationship between perceived organizational support and job outcomes: 20 years of research. Journal of Business Research, 62(12), 1027-1030.

Robbins, S. P. (2005). Organizational Behavior. Englewood Cliffs: Pearson Prentice Hall.

Robbins, S. P. \& Judge, T. A. (2009). Organizational Behavior. New Jersey: Pearson Prentice Hall.

Rollinson, D. \& Broadfield, A. (2002). Organizational Behavior and Analysis: An Integrated Approach. Harlow: Pearson Education.

Silverthorne, C. (2001). A test of the path-goal leadership theory in Taiwan. Leadership \& Organization Development Journal, 22(4), 151-158.

Spector, P. E. (1997). Job Satisfaction: Application, Assessment, Causes, and Consequences. Thousand Oaks: Sage Publications.

Stevens, J., Beyer, J. \& Trice, H. (1978). Assessing personal role and organizational predictors of managerial commitment. Academy of Management Journal, 21(3), 380-396.

Swanson, R. G. \& Johnson, D. A. (1975). Relation between peer perception of leader behavior and instructor-pilot performance. Journal of Applied Psychology, 60(2), 198-200.

Tansky, J. W. \& Cohen, D. J. (2001). The relationship between organizational support, employee development, and organizational commitment: An empirical study. Human Resource Development Quarterly, 12(3), 285-300.

Valez, G. V. (1972). A study of faculty satisfaction and dissatisfaction with the intrinsic and extrinsic job factors in Columbia University. Dissertation Abstracts International, 33(3), 997-A.

Ward, E. \& Davis, E. (1995). The effect of benefit satisfaction on organization commitment. Compensation \& Benefits Management, 11(3), 35-40.

Weiss, D., Dawis, R., England, G. \& Lofquist, L. (1967). Manual for the Minnesota Satisfaction Questionnaire. Minneapolis: University of Minnesota Industrial Relations Centre.

Weiss, H. (2002). Deconstructing job satisfaction: Separating evaluations, beliefs and affective experiences. Human Resource Management Review, 12(2), 173-194.

Williams, L. J. \& Hazer, J. T. (1986). Antecedents and consequences of satisfaction and commitment in turnover models: A reanalysis using latent variable structural equation methods. Journal of Applied Psychology, 71(2), 219-231.

Yamane, T. (1970). Statistics - An Introductory Analysis. Tokyo: John Weatherhill.

Yang, J. (2010). Antecedents and consequences of job satisfaction in the hotel industry. International Journal of Hospitality Management, 29(4), 609-619.

Yousef, D. A. (2000). Organizational commitment: A mediator of the relationships of leadership behavior with job satisfaction and performance in a non-western country. Journal of Managerial Psychology, 15(1), 6-28. 